\title{
Antimicrobial activity of organic honeys against food pathogenic bacterium Clostridium perfringens
}

\author{
Djamila Oinaala $\cdot$ Marjatta Lehesvaara • \\ Ulrike Lyhs • Carina Tikkanen-Kaukanen
}

Received: 29 October 2014 / Accepted: 22 February 2015 / Published online: 13 March 2015

(C) The Author(s) 2015. This article is published with open access at Springerlink.com

\begin{abstract}
Against Clostridium perfringens, a common cause of food poisoning, antimicrobial activity and methyglyoxal (MGO) contents of six multifloral organic honeys were investigated, five from Finland and one from Argentinian and Hungarian origin. For the antimicrobial assessment, a disc diffusion method was used with zone of inhibition expressed as a diameter. Four honeys had inhibitory activity (diameter $>8 \mathrm{~mm}$ ) compared to control (diameter of $6.1 \mathrm{~mm} \pm 1.5$ ) at the concentration of $50 \%(w / v)$. The highest activity was induced by North Carelien multifloral honey F with willow herb as the main floral source (diameter of $14.3 \mathrm{~mm}$ \pm 0.6 ), followed by other North Carelien multifloral honey $\mathrm{E}$ (diameter of $11.0 \mathrm{~mm} \pm 2$ ) with clover as the main floral source. For honey $\mathrm{F}$, the minimal inhibitory concentration (MIC) was $20 \%(w / v)$. MGO was quantified by HPLC and varied from 22 to $27 \mathrm{mg} / \mathrm{kg}$. MGO had no correlation to the detected activity. This is a novel finding on the antibacterial activity of native organic honeys and against $C$. perfringens.
\end{abstract}

D. Oinaala $\cdot$ U. Lyhs $\cdot$ C. Tikkanen-Kaukanen $(\bowtie)$ Ruralia Institute, University of Helsinki, Lönnrotinkatu 7, 50100 Mikkeli, Finland

e-mail: carina.tikkanen-kaukanen@helsinki.fi

M. Lehesvaara

University of Applied Sciences, Mikkeli, Finland

C. Tikkanen-Kaukanen

Finnish Organic Research Institute, Mikkeli, Finland
Keywords Organic honey - Antimicrobial activity · Antibacterial activity $\cdot$ C. perfringens $\cdot$ Food poisoning

\section{Introduction}

It is now widely accepted that honey has antimicrobial activity and that this is dependent upon a variety of different modes of action (Molan 1992). Antibiotic resistance is a serious problem worldwide and has made the search for new antimicrobial compounds highly important (Dixon 2003; Laxminarayan et al. 2013). Antibiotics have been associated with development of antibiotic-resistant bacteria that can cause foodborne illness. On the other hand, food market trends are constantly changing. Nowadays, consumers have become more demanding and more aware in relations of food that they eat. They search for food of higher quality, which means less extreme treatments and/or additives, more foods with fresh and authentic attributes (Gould 1992) and sustainable diets (Kesse-Guyot et al. 2013). These changes have important and significant implications from a microbiological point of view. Microbial growth in foods has negative consequences such as consumer hazards due to the presence of pathogenic organisms or microbial toxins, and it may also result in economic losses as a result of spoilage (Davidson 2001). Inactivation, growth delay, or growth prevention of spoilage and pathogenic microorganisms are the first steps for food preservation. The use of antibiotics in food production is restricted and must be minimized; this concerns especially organic food. Antimicrobial 
activity of organic honeys may give a solution for preservation of organic food products. According to the Organic World yearbook (2013), sales of organic products were approximately 21.5 billion euros in 2011, an increase of $9 \%$ over 2010. In Europe, $2.2 \%$ of the agricultural area, and in the European Union, $5.4 \%$ of the agricultural area is organic.

Honey has been used as a traditional medicine for centuries (Zumla and Lulat 1989). Many in vitro studies have shown antimicrobial activity of different honeys against a wide range of skin-colonizing and foodborne bacterial species, including antibiotic-resistant bacteria (Mundo et al. 2004; Lusby et al. 2005; Lin et al. 2009; Kwakman et al. 2008, 2010). It has been shown that also in vivo honey has beneficial actions against wound infections (Robson et al. 2009), and licensed honey products are widely used in wound care (Cooper et al. 2010). Recently, significant antimicrobial activity of engineered organic honey against wound infections has been reported (Dryden et al. 2014). SurgihoneyTM is a licensed sterile product which has been developed for wound care and as a dressing for wounds. It consists of honey which has been modified to produce different potencies of antimicrobial activity.

Several properties in honey contribute to its antimicrobial activity. The main antimicrobial factors are high osmolarity, low $\mathrm{pH}$, and hydrogen peroxide (White et al. 1963; Molan 1992, 2001). Also, phenolic compounds may contribute to antimicrobial activity (Estevinho et al. 2008). Revamil ${ }^{\circledR}$ and Manuka honeys, the two medicinal honeys mostly used in wound management, have additional antimicrobial mechanisms. In Manuka honey, the main active component is methylglyoxal (Mavric et al. 2008) and from Revamil ${ }^{\circledR}$ honey, an antimicrobial peptide, bee defensin-1 has been identified (Kwakman et al. 2010).

Many studies on antimicrobial activity of honey have been conducted in non-European countries (Voidarou et al. 2011), and especially in the southern hemisphere (Lusby et al. 2005; Lin et al. 2009; Allen et al. 1991; Irish et al. 2011). New Zealand Manuka honey is widely studied and used clinically. However, other honeys with different floral backgrounds and equivalent inhibitory activity have been found (Lusby et al. 2005).

Clostridium perfringens type A is known to cause a broad spectrum of human and animal diseases. It is one of the most common causes of foodborne illness in Europe, Japan, and the USA (Wen and McClane 2004). Antibiotic-resistant $C$. perfringens strains are becoming a major health concern. A study by Teuber (1999) indicated that copious use of antibiotics in agriculture is promoting a large antibiotic resistance problem in foodborne pathogens, including $C$. perfringens. Because of the rise of drug-resistant strains of C. perfringens, new antimicrobials are needed. In the present study, antimicrobial activity and methylglyoxal contents of five multifloral organic honeys from different parts of Finland and one originating from Argentina and Hungary against food poisoning bacteria Clostridium perfringens were investigated.

\section{Materials and methods}

Honey samples

One of the studied honeys was a mixture of organic honeys from Hungary and Argentina made by the producer (referred here as A). All the other honeys examined (referred as B-F) were produced in different parts of Finland. The following organic honeys were studied: honey produced in Eastern Finland, Haarajärvi, North Karelia (referred here as B); honey obtained from Central Finland, Korpilahti, Jyväskylä, (referred here as C); and honey obtained from Eastern Finland Ihastjärvi, South Savonia (referred here as D). Organic multifloral honeys A, B, C, and D were purchased from the local supermarkets in March of 2012. Two of the studied honeys were provided by local beekeepers, North Karelia organic honey from Eastern Finland Hoilola, Joensuu (referred here as F), and organic honey from Eastern Finland Ilomantsi, North Karelia (referred here as E). Honey samples provided by local beekeepers were obtained in ready commercial package. All the studied honeys were multifloral and contained different floral sources. The major floral source was reported to the Finnish honeys B, C, D, E, and F. The major floral sources of honeys B and C were wild raspberry (genus Rubus), willow herb (Epilobium angustifolium), lingonberry (Vaccinium vitis-idea), and bilberry (Vaccinium myrtillus). In honey $\mathrm{D}$, the nectar had been collected mainly from wild raspberry (genus Rubus) and lingonberry ( $V$. vitis-idea) flowers. In honey $\mathrm{E}$, the main floral source was clover (genus Trifolium) and for honey $\mathrm{F}$ willow herb (E. angustifolium). Honey $\mathrm{D}$ had been treated by quick heat treatment at $50{ }^{\circ} \mathrm{C}$ in order to melt honey into viscose liquid form. All the other studied honeys were untreated. 
Bacterial strain and culture conditions

The bacterium used in this research was a $C$. perfringens type A strain ( $\alpha$-toxin positive and netB toxin gene negative) isolated from turkey with necrotis enteritis (NE) infection (CLO 555, strain collection of the Finnish Food Safety Authority (Evira)). The strain was cultured on blood agar containing $5 \%$ defibrinated sheep blood and incubated anaerobically (AnaerobicCult A, Merck, Darmstadt, Germany) at $37^{\circ} \mathrm{C}$ for 24 to $48 \mathrm{~h}$.

Preparation of the honey samples

All the tested honeys were stored in the dark at room temperature until used for antimicrobial assays. The honey solution was handled aseptically. Fifty grams of each honey was weighed and mixed into a $100 \mathrm{ml}$ of sterile distilled water to achieve $50 \%(w / v)$ solution, and the solution was further diluted in sterile distilled water to achieve solutions containing 25, 20, and $15 \%(w / v)$. The solutions were used to saturate paper discs in order to determine zones of inhibition.

To evaluate the osmotic pressure's effect, artificial honey was used. A sugar solution [80 \% (w/v) sugar], serving as an artificial honey control, was prepared by dissolving $40 \mathrm{~g}$ of fructose, $30 \mathrm{~g}$ of glucose, $8 \mathrm{~g}$ of maltose, and $2 \mathrm{~g}$ of sucrose in $100 \mathrm{ml}$ of sterile distilled water and used diluted as described for the honey samples.

Assessment of antimicrobial activity and determination of minimal inhibitory concentration

Antimicrobial activity of honey was analyzed using a disc diffusion assay according to the technique described by Bauer et al. (1966) with adaptation by Taormina et al. (2001). Screening the susceptibility of bacteria to honeys was carried out with the honey concentration of $50 \%(w / v)$. Sterile paper discs (Whatman-type 3) $5 \mathrm{~mm}$ of diameter were prepared. In the preliminary screening, sample discs were impregnated with $5 \mathrm{mg}$ of honey in $10 \mu \mathrm{l}$ of honey solution at the concentration of $50 \%(w / v)$. When the minimal inhibitory concentration (MIC) value was determined, $20 \mu \mathrm{l}$ of the $50 \%$ honey solution was used. The control discs were impregnated with $1 \mu \mathrm{g}$ of penicillin $\mathrm{G}$ (Oxoid Microbiology Products, UK) or with sugar solution (described above) or were impregnated with water.
Discs represented positive (the first) and negative controls (the second and the third).

Using a loop, 3-5 identical colonies were picked from a blood agar plate (Biotrading) and transferred into a tube containing $5 \mathrm{ml}$ of brain heart infusion (BHI) broth (Becton Dickinson). The broth culture was incubated under anaerobic conditions at $37{ }^{\circ} \mathrm{C}$ until it achieved or exceeded the turbidity of $0.5 \mathrm{McF}$ arland standard (a 0.5 McFarland standard was prepared by mixing $0.05 \mathrm{ml}$ of $1 \% \mathrm{BaCl}_{2} \cdot 2 \mathrm{H}_{2} \mathrm{O}$ with $9.95 \mathrm{ml}$ of $1 \% \mathrm{H}_{2} \mathrm{SO}_{4}$ ). The incubation time was $2-6 \mathrm{~h}$. After adjusting the turbidity of inoculum suspensions, a sterile cotton swab was dipped into the adjusted suspension and streaked over the entire sterile BHI agar surface. Duplicates of the antimicrobial discs with $10 \mu \mathrm{l}$ of $50 \%$ $(w / v)$ of honey solutions and positive and negative controls were dispensed onto the surface of inoculated agar plate. After incubation time at $37{ }^{\circ} \mathrm{C}$ for $24 \mathrm{~h}$ under anaerobic conditions, zones of inhibition surrounding the discs were measured with a ruler and the average of the diameter of the zones were recorded. At least two independent experiments were carried out.

Honey F was selected for MIC analysis by using agar disc diffusion. In this step, the same technique as described in the preliminary screening was used with the exception that paper discs were impregnated with $20 \mu \mathrm{l}$ of honey solution. The tested concentrations were 50 , 25,20 , and $15 \%$ corresponding discs containing 10,5 , 4 , and $3 \mathrm{mg}$ of the honey, respectively. Determined MIC corresponds to the lowest concentration, for which the zone of inhibition showed good inhibitory activity. The determination of MIC for honey F was carried out in two independent experiments.

\section{Quantification of methylglyoxal}

Methylglyoxal and $o$-phenylenediamine were obtained from Sigma-Aldrich Finland. Acetic acid and HPLC grade methanol used for mobile phases of HPLC were from VWR International. Water for sample and solution preparations was obtained from Millipore Synergy water purification system. HPLC system (Merck Hitachi) consisted of D-6000 Interface, L-6200 A Intelligent pump, L-4250 UV/VIS detector, As 2000 Autosampler, and Merck RP-18 column (LiChroCART 124-4, $5 \mu \mathrm{m}$ ).

For longer storage, the honeys were kept frozen in $-20{ }^{\circ} \mathrm{C}$ before methylglyoxal (MGO) determination. For the quantification of MGO in honeys, the honey 
samples were treated with $o$-phenylenediamine (OPD), which reacts with MGO to form quinoxaline derivative (2-methylquinoxaline). This derivative was analyzed by HPLC using UV detection. Shortly, honeys ( $2.5 \mathrm{~g}$ ) were dissolved in HPLC grade water $(30 \% w / v)$ and then treated with $2 \%(w / v)$ OPD in $0.5 \mathrm{M}$ phosphate buffer $(0.75 \mathrm{ml}, \mathrm{pH} 6.5)$ for $16 \mathrm{~h}$. Reactions were performed in the dark at room temperature. After membrane filtration $(0.45 \mu \mathrm{m})$, samples were analyzed using HPLC system according to the method described by Mavric et al. (2008). Two replicates were performed for each honey and the average is reported. External calibration of HPLC system was performed using four standards (3, $6,15$, and $30 \mathrm{mg} / \mathrm{l})$. Standards were prepared from MGO and they were treated and analyzed like samples.

The quinoxaline derivative of MGO was detected with UV at $312 \mathrm{~nm}$ and it was eluted at retention time $43 \mathrm{~min}$ in chromatograms. The recovery of MGO was validated by adding a known amount $(30 \mu \mathrm{g})$ of MGO to honey samples $(2.5 \mathrm{~g})$ which were analyzed using the HPLC system. The recovery was 100-101\%, when calculated as follows:

Recovery $\%=100 \times($ Calculated content of MGO in spiked sample $) /($ Calculated concentration of MGO in no-spiked sample $)$.

\section{Results and discussion}

Screening the susceptibility of bacteria to honeys and determination of minimal inhibitory concentration

In the preliminary screening, all the honeys samples were tested against $C$. perfringens type A strain. The concentrations of the honey solutions were $50 \%(w / v)$ $(5 \mathrm{mg})$. The activity of the tested honeys was expressed by zone of inhibition (Table 1). From all the tested honeys, Finnish organic honeys B, C, E, and F showed higher antimicrobial activity than water control (diameter of zone of inhibition $>5.2 \mathrm{~mm} \pm 0.5$ ) and artificial honey sugar solution (diameter of zone of inhibition $6.1 \mathrm{~mm} \pm 1.5$ ). The broadest zone of inhibition against C. perfringens was induced by honey $\mathrm{F}$ (diameter of zone of inhibition $14.3 \mathrm{~mm} \pm 0.6$ ) followed by honey $\mathrm{E}$ (diameter of zone of inhibition $11 \mathrm{~mm} \pm 2$ ) and honey B

Table 1 Growth inhibition expressed as zone of inhibition diameter $(\mathrm{mm})$ of the organic honeys (A-F) and sugar solution at the concentration of $50 \%(w / v)$ against C. perfringens

$\begin{array}{llc} & \text { C } & 7.5 \pm 0.7 \\ & \text { D } & 5 \pm 0 \\ & \text { E } & 11 \pm 2 \\ & \text { F } & 14.3 \pm 0.6 \\ & \text { SS } & 6.1 \pm 1.5 \\ S S \text { sugar solution, } P \text { pos- } & \text { P } & 30.8 \pm 1.4 \\ \text { itive control, } N \text { negative } & \text { N } & 5.2 \pm 0.5 \\ \text { control }\left(\mathrm{H}_{2} \mathrm{O}\right) & & \end{array}$

with the zone of inhibition diameter of $8.3 \mathrm{~mm} \pm 2$ and honey $\mathrm{C}$ with the zone of inhibition diameter of $7.5 \mathrm{~mm}$ \pm 0.7 ; honeys A and D did not show any antibacterial activity against $C$ perfringens. Negative water control did not show any activity, and positive antibiotic control was constantly high (diameter of zone of inhibition of $30.8 \mathrm{~mm} \pm 1.4)$.

After screening the organic honeys against C. perfringens, honey $\mathrm{F}$ that showed the highest antibacterial activity was tested for the minimum inhibitory concentration (MIC), the lowest concentration of honey inhibiting visible growth of the bacteria. MIC was determined by measuring the zone of inhibition (Table 2). Twenty microliters of the honey concentrations 50, 25, 20 , and $15 \%$ were pipetted on the discs containing 10 , 5,4 , and $3 \mathrm{mg}$ of the honey, respectively. Honey concentrations of 50,25 , and $20 \%$ induced better antimicrobial activity than artificial honey, sugar solution SS

Table 2 Determination of the MIC (\%) for organic honey $\mathrm{F}$ sample against $C$. perfringens

\begin{tabular}{lllll}
\hline Sample & $50 \%$ & $25 \%$ & $20 \%$ & $15 \%$ \\
& $10 \mathrm{mg}$ & $5 \mathrm{mg}$ & $4 \mathrm{mg}$ & $3 \mathrm{mg}$ \\
\hline $\mathrm{F}$ & +++ & ++ & +++ & ++ \\
$\mathrm{SS}$ & + & ++ & ++ & $\mathrm{NA}$ \\
\hline
\end{tabular}

MIC corresponds to the lowest concentration of honey, for which the zone of inhibition was visually detectable

Results are based on two individual experiments

+ low inhibition (6-7 mm), ++ moderate inhibition (7-9 mm), +++ good inhibition (>10 mm)

SS sugar solution, NA not analyzed 
(Table 2). Down to the dilutions of 25 and $20 \%$, the sugar effect increased in the control, but was lower than induced by the corresponding honey dilution. At $15 \%$ concentrations, the results were not clear and the zones of inhibition could not be distinguished. Honey F showed higher antimicrobial activity against C. perfringens down to the concentration of $20 \%$ than the control sugar solution. For honey F, the MIC value was thus $20 \%$ (4 mg).

There are many factors in honey that effect on the growth of $C$. perfringens. $C$. perfringens is not tolerant of low water activity $\left(\mathrm{a}_{\mathrm{w}}\right)$, reported values for tolerance being between 0.93 and 0.97 (Labbe 1989). Honey is a supersaturated sugar solution with $0.56-0.62 \mathrm{a}_{\mathrm{w}}$ (Molan 1992), which partly explains the inhibitory activity against $C$. perfringens. In our study, a sugar control, artificial honey, was used to eliminate the hyperosmotic effect of honey in the results. Antimicrobial activity was recorded when the zone of inhibition was higher than induced by control. Thus, in honeys B, C, E, and F, the antimicrobial activity results from additional factors to sugar.

Like most microorganisms, C. perfringens initiate growth most readily at neutral $\mathrm{pH}$, although excellent growth occurs between pH 6 and 7. Smith (1972) reported that growth of $C$. perfringens is severely limited at $\mathrm{pH} \leq 5.0$ and $\mathrm{pH} \geq 8.3$. The $\mathrm{pH}$ of honey is between 3.2 and 4.5. The most active honey $\mathrm{F}$ showed activity in dilutions up to $20 \%$ with raised $\mathrm{pH}$. In honey $\mathrm{F}$, at least, this suggests that there may be also other factors than $\mathrm{pH}$ that act as antimicrobials.

The variation on antibacterial activity of the honeys could be attributed to the floral source. In honey F, the main floral source was willow herb. In our previous study with Finnish monofloral honeys (Huttunen et al. 2013), we found that the best antimicrobial activities were received with willow herb (E. angustifolium), heather (Calluna vulgaris), and buckwheat (Fagopyrum esculentum) honeys against the studied human pathogenic streptococcal and staphylococcal strains. In the present study, honey $\mathrm{E}$ had the second best activity after honey F. In honey E, the major nectar source was clover. Clover honey has been reported to possess antimicrobial activity against Pseudomonas aeruginosa (Lu et al. 2013). In honeys B and C, the antimicrobial activity was quite equal. The major floral sources in honeys $\mathrm{B}$ and $\mathrm{C}$ were wild raspberry, willow herb, lingonberry, and bilberry. In honey $\mathrm{D}$, which was negative, the major sources for the nectar were wild raspberry and lingonberry. The floral source of honey A was not reported.

The geographic region where the honey is produced may influence on antimicrobial activity of honey. In the present study, four of the five Finnish organic honeys had antimicrobial activity. The main difference compared to the active honeys was that the non-active honey $\mathrm{D}$ had been treated by heating shortly at $50{ }^{\circ} \mathrm{C}$ to melt crystals. One may speculate that heating have destroyed the active components. All the other Finnish honeys had crystals and were untreated. Honey A from Argentina and Hungary was reported to be untreated and contained crystals, but it did not show inhibitory activity. The flower source was not reported by the manufacturer. The reason for the inactivity remains unsolved. In the present work, the effect of hydrogen peroxide cannot be excluded because neither the heat treatment nor catalase addition was included in the study.

Kokubo et al. (1984) found spores of Bacillus and Clostridium in honeys from processing plants and retailers. Of the studied 71 samples, 6 contained C. perfringens. In connection to this, it was reported that the growth of Bacillus cereus strains was not inhibited by honeys they investigated (Taormina et al. 2001). Higher tolerance of $C$. perfringens against honey was not seen in our study. Native organic honeys have not been investigated before as regards their antimicrobial activity, and they may even have unknown antimicrobial factors. In Finland, organic honey production is regulated by the European Commission and controlled by the Finnish Food Safety Authority, Evira.

\section{Quantification of methylglyoxal in the honeys}

In addition to the main antimicrobial factors of honey, namely high osmolarity, low $\mathrm{pH}$, and hydrogen peroxide, in Manuka honey, the main active component is methylglyoxal (MGO) (Mavric et al. 2008). In Manuka honey, the MGO concentrations are high ranging from 38 to $761 \mathrm{mg} / \mathrm{kg}$, up to 100 -fold higher compared to non-Manuka honeys (Mavric et al. 2008). In the present study, we showed that the amounts of MGO were quite equal in all the studied organic honeys including inactive honeys A and D. MGO contents varied from 22 to $27 \mathrm{mg} / \mathrm{kg}$ (Table 3), which is tenfold higher than in conventionally produced non-Manuka honeys. There was no correlation between MGO and antimicrobial activity of the honeys. In the studied organic honeys, the antimicrobial activity against $C$. perfringens is thus 
Table 3 Methylglyoxal (MGO) in the organic honey samples A-F (data given in $\mathrm{mg} / \mathrm{kg}$ )

\begin{tabular}{ll}
\hline Honey sample & MGO \\
\hline A & 25 \\
B & 27 \\
C & 22 \\
D & 27 \\
E & 26 \\
F & 26 \\
\hline
\end{tabular}

due to other factors than MGO, and those factors remain here unknown.

Because of increasing drug resistance also against $C$. perfringens strains, new antimicrobials are needed. Antibacterial activity of several conventional honeys has been investigated for their potential action against foodborne pathogens (Taormina et al. 2001). Our data show that from the six organic honeys tested, four had antibacterial action, and two of the honeys had no activity against $C$. perfringens strain. There are no previous studies on the antimicrobial activity of honeys against $C$. perfringens. The effect of organic regime of the bees on antimicrobial activity of the organic honeys remains open. The importance of the present work is especially in protection against food spoilage bacteria, here shown for $C$. perfringens.

\section{Conclusions}

In conclusion, we here report for the first time the antibacterial activity of native organic honeys and activity of honey against $C$. perfringens, a food poisoning bacterium. The activity was not MGO-dependent and may result from several known and unknown factors. In this study and as also shown in our previous studies on conventional Finnish honeys (Huttunen et al. 2013), different honeys have varying and diverse effects on the growth of bacteria. Each organism has unique response profile to different honeys, and the antimicrobial effects are due to combination of several factors in honeys. The present study gives rationale for further studies on antimicrobial activity of organic honeys against food poisoning bacteria including characterization of the antimicrobial components. Considering organic honeys as preservatives in food products, especially in organic food, it would be important to characterize the antimicrobial components and to evaluate the effects of heat and storage on the activity. Clinical intervention would be valuable to confirm the possible protective impact of the studied honeys against C. perfringens infections in humans.

Acknowledgments We thank Anneli Salonen for honey samples and Sari Seppäläinen and Pauliina Isohanni for assistance. This work was supported by Mikkeli University Consortium, Mikkeli, Finland and Finnish Food Safety Authority (Evira), Production Animal and Wildlife Health Research Unit, Seinäjoki, Finland.

Open Access This article is distributed under the terms of the Creative Commons Attribution License which permits any use, distribution, and reproduction in any medium, provided the original author(s) and the source are credited.

\section{References}

Allen KL, Molan PC, Reid GM (1991) A survey of the antibacterial activity of some New Zealand honeys. J Pharm Pharmacol 43:817-822

Bauer AW, Kirby WM, Sherris JC, Turk M (1966) Antibiotic susceptibility testing by a standardized single disk method. Am J Clin Pathol 45:493-496

Cooper RA, Jenkins L, Henriques AFM, Duggan RS, Burton NF (2010) Absence of bacterial resistance to medical-grade manuka honey. Eur J Clin Microbiol Infect Dis 29:12371241

Davidson PM (2001) Chemical preservatives and naturally antimicrobial compounds. In: Doyle MP, Beuchat LR, Montville TJ (eds) Food microbiology. Fundamentals and frontiers. ASM Press, Washington, pp 593-628

Dixon B (2003) Bacteria can't resist honey. Lancet Infect Dis 3: 116

Dryden M, Lockyer G, Saeed K, Cooke J (2014) Engineered honey: in vitro antimicrobial activity of a novel topical wound care treatment. J Glob Antimicrob Resist 2:168-172

Estevinho L, Pereira AP, Moreira L, Dias LG, Pereira E (2008) Antioxidant and antimicrobial effects of phenolic compounds extracts of Northeast Portugal honey. Food Chem Toxicol 46: 3774-3779

Gould GW (1992) Ecosystem approaches to food preservation. Soc Appl Bacteriol Symp Ser 21:59S-68S

Huttunen S, Riihinen K, Kauhanen J, Tikkanen-Kaukanen C (2013) Antimicrobial activity of different Finnish monofloral honeys against human pathogenic bacteria. APMIS 121:827834

Irish J, Blair S, Carter DA (2011) The antimicrobial activity of honey derived from Australian flora. PLoS One 6:e18229

Kesse-Guyot E, Péneau S, Méjean C, de Szabo Edelenyi FS, Galan P, Hercberg S, Lairon D (2013) Profiles of organic food consumers in a large sample of French adults: results from the Nutrinet-Santé cohort study. PLoS One 8:e76998

Kokubo Y, Jinbo K, Kaneko S, Matsumoto M (1984) Prevalence of spore-forming bacteria in commercial honey. Ann Rep Tokyo Metrop Res Lab Pub Health 35:192-196 
Kwakman PHS, Van der Akker JPC, Güclü A, Aslami H, Binnekade JM, de Boer L, Boszhard L, Paulus F, Middelhoek P, te Velde AA, Vandenbroucke-Grauls CM, Schultz MJ, Zaat SA (2008) Medical-grade honey kills antibiotic-resistant bacteria in vitro and eradicates skin colonization. Clin Infect Dis 46:1677-1682

Kwakman PHS, te Velde AA, de Boer L, Speijer D, VandenBroucke-Grauls CMJE, Zaat SA (2010) How honey kills bacteria. FASEB J 24:2567-2582

Labbe RG (1989) Clostridium perfringens. In: Doyle MP (ed) Foodborne bacterial pathogens. Marcel Deker Inc, New York, pp 192-234

Laxminarayan R, Duse A, Wattal C, Zaidi AKM, Wertheim HF, Sumpradit N, Vlieghe E, Hara GL, Gould IM, Goossens H, Greko C, So AD, Bigdeli M, Tomson G, Woodhouse W, Ombaka E, Peralta AQ, Qamar FN, Mir F, Kariuki S, Bhutta ZA, Coates A, Bergstrom R, Wright GD, Brown ED, Cars O (2013) Antibiotic resistance - the need for global solutions. Lancet Infect Dis 13:1057-1098

Lin SM, Molan PC, Cursons RT (2009) The in vitro susceptibility of Campylobacter spp. to the antibacterial effect of manuka honey. Eur J Microbiol Infect Dis 28:339-344

Lu J, Carter DA, Turnbull L, Rosendale D, Hedderley D, Stephens J, Gannabathula S, Steinhorn G, Schlothauer RC, Whitchurch CB, Harry EJ (2013) The effect of New Zealand kanuka, manuka and clover honeys on bacterial growth dynamics and cellular morphology varies according to the species. PLoS One 8:e55898

Lusby PE, Coombes AL, Wilkinson JM (2005) Bactericidal activity of different honeys against pathogenic bacteria. Arch Med Res 36:464-467

Mavric E, Wittmann S, Barth G, Henle T (2008) Identification and quantification of methylglyoxal as the dominant antibacterial constituent of Manuka (Leptospermum scoparium) honeys from New Zealand. Mol Nutr Food Res 52:483-489
Molan P (1992) The antibacterial activity of honey 1 . The nature of the antibacterial activity. Bee World 73:5-28

Molan P (2001) Why honey is effective as a medicine. Bee World $82: 22-40$

Mundo MA, Padilla-Zakour OI, Worobo RW (2004) Growth inhibition of foodborne pathogens and food spoilage organisms by select raw honeys. Int J Food Microbiol 97:1-8

Organic World Yearbook. Key Results. In: The World of Organic Agriculture 2013 [online] www.organic-world.net/yearbook2013.html. Accessed 6 Oct 2014

Robson V, Dodd S, Thomas S (2009) Standardized antibacterial honey $\left(\right.$ Medihoney ${ }^{\mathrm{TM}}$ ) with standard therapy in wound care: randomized clinical trial. J Adv Nurs 65:565-575

Smith L (1972) Factors involved in the isolation of Clostridium perfringens. J Milk Food Technol 35:71-76

Taormina PJ, Niemira BA, Beuchat LR (2001) Inhibitory activity of honey against foodborne pathogens as influenced by the presence of hydrogen peroxide and level of antioxidant power. Int J Food Microbiol 69:217-225

Teuber M (1999) Spread of antibiotic resistance with food-borne pathogens. Cell Mol Life Sci 56:755-763

Voidarou C, Alexopoulos A, Plessas S, Karapanou A, Mantzourani I, Stavropoulou E, Fotou K, Tzora A, Skoufos I, Betzirtzoglou E (2011) Antibacterial activity of different honeys against pathogenic bacteria. Anaerobe 17:375-379

Wen Q, McClane BA (2004) Detection of enterotoxigenic Clostridium perfringens type A isolates in American retail foods. Appl Environ Microbiol 70:2685-2691

White JW, Subers MH, Schepartz AI (1963) The identification of inhibine, the antibacterial factor of honey, as hydrogen peroxide and its origin in honey glucose-oxidase system. Biochim Biophys Acta 73:57-70

Zumla A, Lulat A (1989) Honey-a remedy rediscovered. J R Soc Med 82:384-385 